\title{
Conceptual approaches for building a balanced portfolio of projects in oil and gas companies in exploration and production sector
}

\author{
Konstantin Molchanov ${ }^{1, *}$, Natalia Romasheva ${ }^{1}$ \\ ${ }^{1}$ Saint-Petersburg Mining University, Vasilievsky Island, str. 21 line, 2, St. Petersburg, 199106, Russia
}

\begin{abstract}
Uncertainties such as price volatility, supply and demand, global warming, technological progress, geopolitical situation, force the capital-intensive oil and gas sector to create a flexible portfolio of projects to proactively respond to changes. In an increasingly complex and uncertain environment, oil and gas companies around the world face continued pressure. It has become difficult to make strategic decisions and build long-term plans, so it has become vital to have a balanced portfolio. We suggest that in order to achieve the goals and maximize profitability, companies need to develop indicators for balanced portfolio, which will allow to evaluate the portfolio and rank the current and potential projects in order to create flexibility with minimal risk. In the article, we analysed modern approaches and benchmarked companies` tools for portfolio management, current situation in industry, identified risks and indicators for evaluation. We received the tool for quantitative evaluation for portfolio.
\end{abstract}

\section{Introduction}

In today's business environment, managers and companies face serious competition for scarce resources, shrinking opportunities and the ever-changing demands of internal and external stakeholders. In addition, projects are constantly added, modified and removed in accordance with business cycle and changing market conditions. As a result, the backlog of "necessary" projects requires resources beyond the capacity of management, which almost requires constant review and re-ranking projects.

Despite volatile prices, it has nevertheless been possible to predict the range of price changes. But now large fluctuations in commodity prices, uncertainties about the future of energy consumption and its types and increasingly complex trade negotiations around the world are undermining the traditional foundations of supply and demand, creating many new problems with no immediate answers. In an increasingly complex and uncertain environment, oil and gas companies around the world face continued pressure. Arctic is new place for production [1]. Many companies start their project with unpredictable results in this region [2]. It has become difficult to make strategic decisions and build long-term plans, so it has become vital to have a balanced portfolio [3].

Portfolio management is the science of making decisions about investing resources in accordance with the goals of the organization. It is the definition of strengths and weaknesses, opportunities and threats in the selection of investment objects, determining the ratio of equity and debt, domestic and international development, as well as many other parameters that arise in an attempt to maximize returns at the selected level of risk.

Many organizations are currently transforming their business in order reduce costs, reinstate customer focus, restore stakeholder trust, and/or introduce new business models [4]. Selecting unsuitable projects that do not support the corporate strategy or do not add value can limit capital for the "right projects". The purposes of project portfolio management are [5]:

- to maximize the value of the portfolio;

- to balance portfolio;

- to align projects with strategic objectives.

According to PMBOK[6] project portfolio management consists of the following processes (Fig.1).

One of the key processes is portfolio balancing - the process of creating a specific set of portfolio components to achieve strategic goals [7]. Portfolio balancing is the process of developing the priority projects in the portfolio, consistent with the strategic goals of the organization. The required indicators are usually set by the manager to allocate financial or other resources, among competing projects within the portfolio.

A balanced portfolio of projects is a combination of components that allows the company to develop steadily in any environment. This portfolio consists of projects at different stages, in different countries, aimed at both long-term development and short-term benefits. 


Aligning Process Group
Identify components
Categorize components
Evaluate components
Select components
Identify portfolio risks
Prioritize components
Develop Portfolio risk responses
Balance portfolio
Communicate portfolio Adjustment
Authorize components

\author{
Monitoring and Control Process \\ Group \\ Monitoring and Control portfolio \\ risks \\ Review and Report Portfolio \\ performance
}

Monitoring business strategy changes 
A portfolio management approach that neglects risk can lead to an unbalanced portfolio, and without taking into account the risks at the portfolio level, the organization may not create reserve and prepare for negative changes in the future.

Taking into account different methods of portfolio management we validate more expanded and specific quantitative approach for portfolio assessment, considering situation in oil and gas industry. The goals of the study are to determine external risks in industry and develop indicators for building flexible portfolio.

\section{Materials and Methods}

The hypothesis of the study is based on the assumption that oil and gas companies face great challenges and high volatility. Therefore, the tool developed by authors is crucial for evaluation current and creating balanced portfolio of projects, allows companies to achieve goals despite of various external changes. Therefore, it is necessary to define risks in industry, to set various indicators and to offer their assessment for the portfolio building.

At the first stage, desk research was carried out:

1. Literature of current approaches for portfolio management was reviewed

2. Information on the current situation of the oil and gas industry and prospects for its development was collected.

3. Reports of various analytical agencies were studied.

4. Financial statements, strategies and portfolio management methods in 7 largest independent oil and gas companies in the world (Equinor, ENI, Chevron, Exxon, Shell, Total, BP). Reports of various analytical agencies were studied.

At the second stage, different analysis was carried out:

1. PEST-analysis oil and gas industry and identification for various risk factors (Fig.2)

2. Benchmarking of operational and financial results, strategies and portfolio management methods was carried out. The portfolios of these companies are heterogeneous: they comprise projects of various size, nature, geography and etc. Analysis of these companies allowed us to determine the indicators for evaluating current portfolio and building the optionality, ranking current projects by the level of impact, abandon projects that don't match company strategy, as well as ranking potential projects based on the assessment of the current portfolio.

3. 20 indicators were selected that affect the companies` key financial and operational indicators.

4. The study the opinions of 50 experts of different oil and gas companies was carried out. Respondents were asked to respond the question, which indicators are affected to flexibility of the portfolio. 12 indicators were defined by experts (Fig. 2).

5. An evaluation equation for each indicator was developed.

Using these indicators for portfolio evaluation, projects ranking projects, will enable companies to build flexible portfolio and cope with high volatility and uncertainties.
Indicator

Position on the market of mergers and acquisitions

The investment cycle of the project

Oil to gas production ratio

Debt to equity ratio

Access to finance

Level of technological progress and innovation

Share in projects

Exploration expenditures

Resource types

Political diversification

Geography diversification

CO2 emissions
Risk

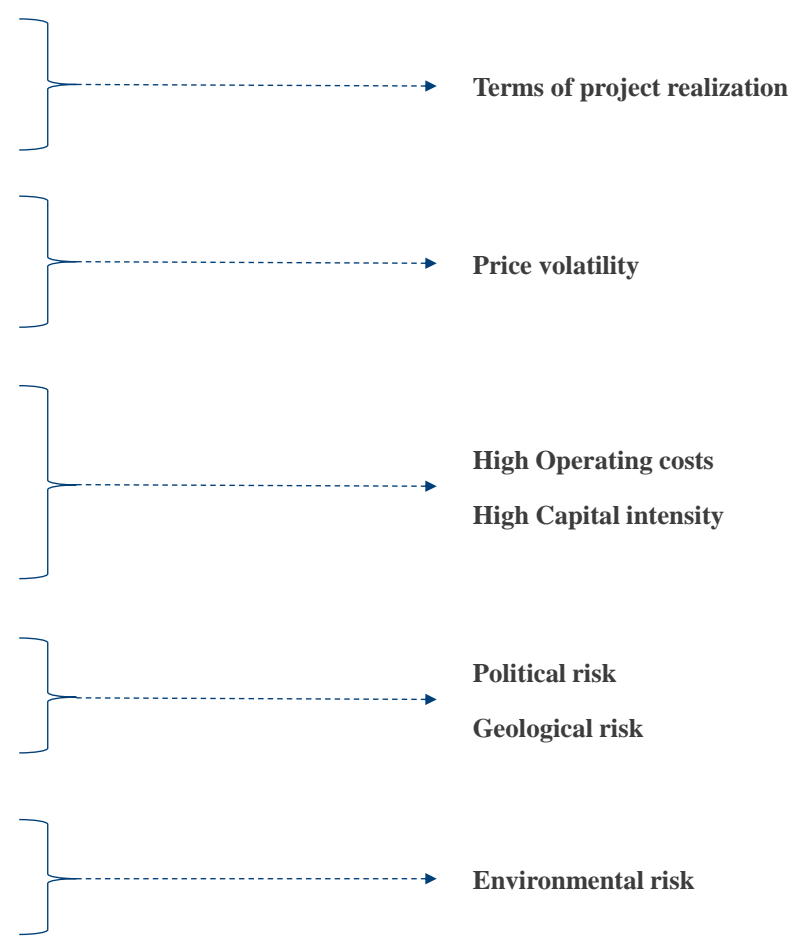

Fig. 2. Identified risks and indicators. 


\section{Results}

Based on the PEST analysis of the industry the following risks were identified (Tab.1):

Various indicators of balanced portfolio based on the companies' activities and expert opinions were identified:

Access to finance. Historically, Bank financing has been the dominant form of external financing for the oil and gas industry. Most companies have a corporate revolving line of credit, which is often syndicated in a number of banks to provide financial flexibility in dayto-day operations.

However, with tighter access to capital and to ensure that investments are in demand by industry, especially for large capital projects, it is important for companies to strive for financial flexibility. Diversified companies with significant long-term debt maturities and revolving loans will have more opportunities to negotiate with creditors than companies with limited financial and operational flexibility. The companies having access to all the following types of financing have the lowest risk [27]:

- Cash flow from operations
- Bank loans

- Public bonds

- Infrastructure funds

- Proceeds from divestments

- Project finance

- Government loans

The assessment of the access to finance is determined by the following equations:

Access to finance $=$ amount of available type of borrowings/ all types of financing

Debt to equity ratio. In our opinion, companies should work with level of leverage very disciplined. It is necessary to use different sources of financing and look for conditions of low interest rates and balance shortterm financial priorities with long-term value creation potential. However, according to the analysis [28] not always low level of leverage provides the best results, which confirms the importance of having the right balance of long-term growth and short-term financial goals. [29-35].

Debt to Equity ratio should be no higher than the industry average (Tab.2). \% of deviation will be equal to the risk level for this indicator.

Table 1. Risks and their identification.

\begin{tabular}{|c|c|}
\hline Risk & Discription \\
\hline Price volatility & $\begin{array}{c}\text { Significant fluctuations in commodity prices are undermining traditional supply } \\
\text { and demand frameworks, creating many new challenges to which there are no } \\
\text { clear answers. }\end{array}$ \\
\hline Term of project realization & $\begin{array}{c}\text { The implementation of projects in the oil and gas sector takes quite a long } \\
\text { period. Companies invest significant funds with the inability to withdraw funds } \\
\text { from the asset in a short time. }\end{array}$ \\
\hline High operating costs & $\begin{array}{c}\text { Depletion of reserves on traditional assets, forcing companies to look for new } \\
\text { deposits on the shelf and extract unconventional resources. Which significantly } \\
\text { increases capital and operating costs. Thereby increasing the risks of the entire } \\
\text { portfolio. }\end{array}$ \\
\hline High capital intensity & $\begin{array}{c}\text { The key objective of any oil and gas company is to maintain production levels } \\
\text { and increase profitability. The impact of various factors can lead to significant } \\
\text { losses and failure to fulfill strategic objectives. }\end{array}$ \\
\hline Political risk & $\begin{array}{c}\text { Geological risks are one of the key problems of oil and gas companies. It is } \\
\text { possible to spend a large amount of money, and stocks will be less than } \\
\text { expected or commercially unprofitable. }\end{array}$ \\
\hline Environmental risk & $\begin{array}{c}\text { The threat of climate change poses a serious challenge to the oil and gas } \\
\text { industry. States of different countries are beginning to regulate CO2 emissions } \\
\text { into the atmosphere, limiting the activities of companies. }\end{array}$ \\
\hline
\end{tabular}

Table 2. $\mathrm{D} \backslash \mathrm{E}$ ratio by majors.

\begin{tabular}{|c|c|c|c|c|c|c|c|}
\hline Company & 2012 & 2013 & 2014 & 2015 & 2016 & 2017 & 2018 \\
\hline Equinor & 0.37 & 0.51 & 0.61 & 0.80 & 0.90 & 0.71 & 0.60 \\
\hline ENI & 0.41 & 0.44 & 0.41 & 0.50 & 0.51 & 0.51 & 0.51 \\
\hline Chevron & 0.09 & 0.14 & 0.18 & 0.25 & 0.32 & 0.26 & 0.22 \\
\hline Exxon & 0.07 & 0.13 & 0.17 & 0.23 & 0.26 & 0.23 & 0.20 \\
\hline Shell & 0.22 & 0.25 & 0.26 & 0.36 & 0.50 & 0.44 & 0.39 \\
\hline Total & 0.47 & 0.45 & 0.61 & 0.58 & 0.54 & 0.46 & 0.46 \\
\hline BP & 0.41 & 0.37 & 0.47 & 0.55 & 0.61 & 0.64 & 0.66 \\
\hline Average & 0.29 & 0.33 & 0.39 & 0.47 & 0.52 & 0.46 & 0.43 \\
\hline
\end{tabular}


Table 3. Investments for R\&D by majors.

\begin{tabular}{|c|c|c|c|c|c|}
\hline Company & 2014 & 2015 & 2016 & 2017 & 2018 \\
\hline Eni & 150 & 156 & 180 & 207 & 221 \\
\hline ExxonMobil & 971 & 1008 & 1058 & 1063 & 1116 \\
\hline Equinor & 476 & 344 & 298 & 307 & 315 \\
\hline Shell & 1222 & 1093 & 1014 & 922 & 986 \\
\hline Chevron & 707 & 601 & 476 & 433 & 453 \\
\hline BP & 663 & 418 & 400 & 391 & 429 \\
\hline Total & 1245 & 980 & 1050 & 912 & 1000 \\
\hline
\end{tabular}

Level of technological progress and innovation. Companies with strong technological capabilities and efficient process can use precedence in any price environment. The development of technologies allows companies to reduce development costs, increase the oil recovery rate, work in places and conditions that are not available to other participants. To determine the required level of investment in $\mathrm{R} \& \mathrm{D}$, it is necessary to analyze the costs of industry leaders in the direction of $R \& D$ (Tab.3) and compare current costs with the average values of companies.

Level of technological progress and innovation is determined by the following equations:

Level of technological progress and innovation= company`s investments for $\mathrm{R} \& \mathrm{D} /$ Investments for $\mathrm{R} \& \mathrm{D}$ by leading company.

Oil to gas production ratio. Another important area of optimization is to increase the share of gas in production. The economic results of oil projects around the world are correlated with fluctuations in oil prices. However, this does not apply to natural gas. Natural gas prices in many parts of the world, especially in the United States, are not strongly correlated with world crude oil prices. Thus, a portfolio consisting of gas and oil projects will be less dependent on oil prices, future-oriented and therefore better diversified relative to price than a portfolio consisting only of oil projects. The Figure 3 shows us increasing share of gas in companies' portfolios.

Gas is strategic importance to the portfolio because of its low level of pollution, although it does not yet play a major role in the company's portfolios. Thus, the ideal ratio of oil and gas in the company's portfolio is 50:50. The change of this ratio leads to an increase in risk.

Oil to gas production ratio $=(50 \%$-Share of gas $) * 2$

Political diversification. Oil investments have always been subject to political uncertainty. Projects that depend on the same political risks will be positively correlated. Negative correlation of projects can also be caused by political uncertainty. A portfolio consisting of one project in each negatively correlated region will be protected from political risk in any region. Diversifying the portfolio can help companies avoid peaks and troughs in one economic region. Every country has a certain level of political risk, which is calculated annually by the academic Aswat Yes Modernom.

To determine the level of political risk in the company's portfolio, use the equations:

Political risk level $=$ Share of production in country $1 *$ Country risk $1+$ Share of production in country $2^{*}$ Country risk $2+$ Share of production in country $\mathrm{N}^{*}$ Country risk $\mathrm{N}$.

Geographic diversification is the practice of diversifying an investment portfolio across different geographical regions in order to reduce overall risk and

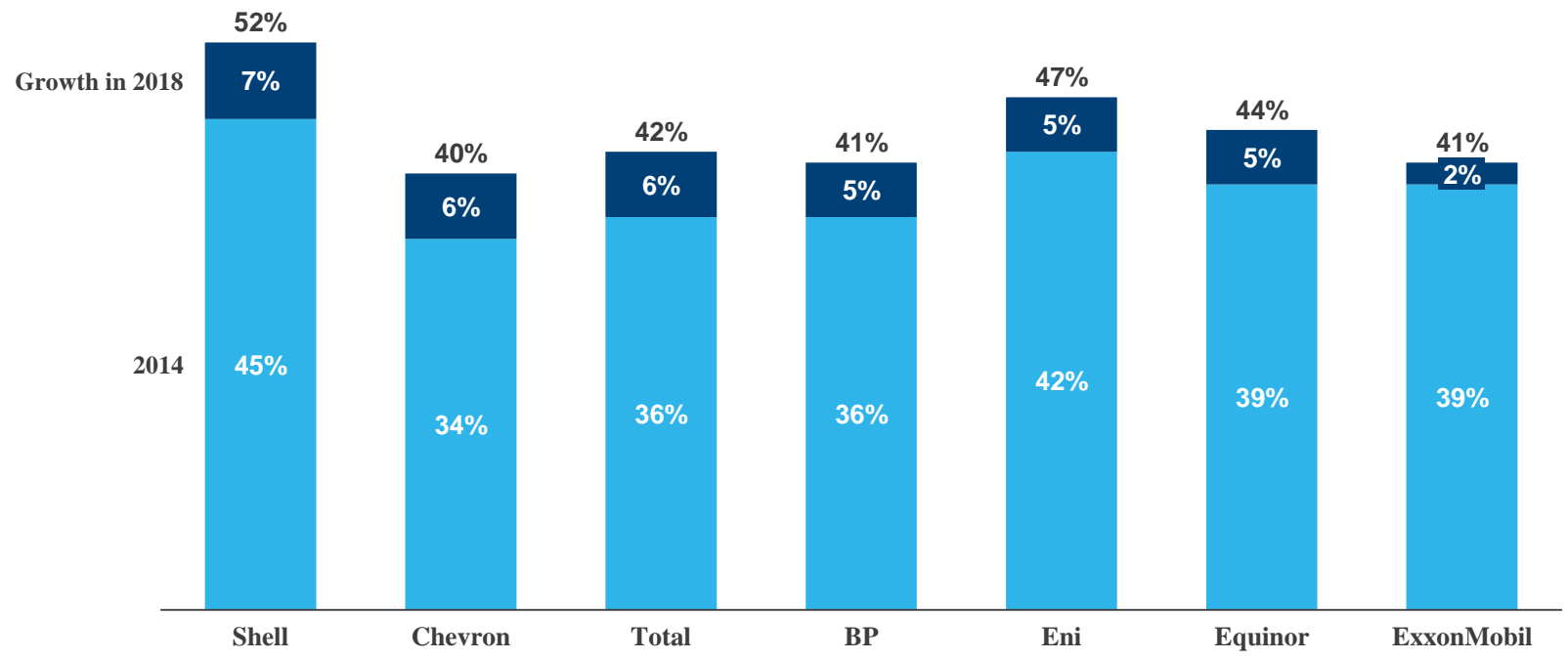

Fig. 3. Share of Gas in production. 
increase the return on the portfolio. Each basin has a certain level of geological risk, and the most balanced portfolio appears to be one in which reserves are equally distributed across different basins. To evaluate the level of risk, it will take the share of reserves from the total volume in the basin with the largest reserves.

Geography risk level $=$ Share of reserves in the particular area / the entire volume.

Exploration expenditures. The main indicator of oil and gas companies is the replenishment of reserves. In order to ensure that the replenishment ratio is equal to the volume of reserves produced, an analysis of oil and gas companies ' exploration expenditures from 2012 to 2018 was carried out and the average unit costs per 1 bar found were calculated (Tab.4). After that, companies need to compare current costs with global data and determine the level of investment for a particular company.

Resources types. Now, five types of resources are allocated:

- Traditional and shallow shelf

- Shale

- LNG

- Deep water

- Unconventional (oil Sands, coal gas)

The era of traditional resources is outdated [36]. Companies need to develop new competencies and implement projects to develop different types of resources. For each company it is necessary to determine the strategic direction and the share of projects for different types of resources.

Companies' cooperation in the implementation of projects is an extremely relevant practice in modern conditions of growth of capital expenditures. Joint ventures allow companies to share different types of risks (financial, geological, and technological), gain competence, implement projects, the scale of which is too large for independent implementation. At the same time, companies with a large number of projects with an operating share have a greater degree of investment optionality and development flexibility than those with minority shares in projects. Thus, companies should take into account the possibility of joint implementation of projects.

The investment cycle of the project. Due to the significant increase in capital costs and 3-4 year cycle of development, companies "lock" their capital in projects, in the current environment, in our opinion, the most flexible approach is to focus on the investment cycle, companies need to either focus on short-term projects, or reduce the implementation time for medium and longterm projects.

Each company has certain competencies and strategies, so to evaluate this indicator it is necessary to compare the investment cycle of current and new projects with the average the investment cycle of projects in the portfolio.

The investment cycle ratio $=$ average time of investment cycle of projects in the portfolio/ investment cycle of current or potential project

Position on market of the M\&A market. For oil and gas companies, M\&A opportunities are a critical part of the portfolio revaluation process [37]. This approach can be used to sell non-core assets and rebalance the portfolio, with the subsequent updating the focus on the best level of profitability. However, companies that actively buy and sell assets in the market based on the short-term situation end up with a suboptimal and untargeted portfolio. Similarly, companies that may have followed a more consistent strategy, but did not consider the current changes in the industry, remained with a less flexible portfolio. Companies should follow a consistent strategy and actively manage their assets. We can evaluate this indicator by following equations:

Position on market of the M\&A market= amount of projects, where company has an opportunity to sell their share* share of production/ total projects

For any company involved in the oil and gas business, carbon risk is a serious problem. Companies are being forced to take increasingly stringent measures on management, disclosure and targets relating to emissions, risks and preparedness. Companies must account for the total $\mathrm{CO} 2$ emissions from their activities.

\section{Discussion}

In this study, we tried to develop indicators for evaluation current portfolio and ranking projects, based on risks in industry and methods of portfolio management using in oil and gas companies. We believe that this approach is quite general and requires

Table 4. Exploration expenditures by majors.

\begin{tabular}{|c|c|c|c|}
\hline Companies & $\begin{array}{c}\text { Opened reserves, } \\
\text { mln b.o.e. }\end{array}$ & $\begin{array}{c}\text { Exploration and appraisal } \\
\text { costs, } \$ \mathrm{mln}\end{array}$ \\
\hline BP & 3279 & 10288 & 3.14 \\
\hline Chevron & 4504 & 10591 & 2.35 \\
\hline Eni & 1573 & 6371 & 4.05 \\
\hline Equinor & 2437 & 11181 & 4.59 \\
\hline ExxonMobil & 4372 & 11457 & 2.62 \\
\hline Shell & 3114 & 20889 & 6.71 \\
\hline Total & 2020 & 9914 & 4.91 \\
\hline Average & 3043 & 11527 & 4.05 \\
\hline
\end{tabular}


adaptation for each company, taking into account its strategic goals and the level of acceptable risk. We have developed a list of 12 criteria and their assessment that allows companies to evaluate their portfolio, but the list may not be exhaustive and requires additional consideration. In the future, we plan to evaluate the portfolio of projects on the example of a particular company and to test the method in various situations related to external and internal changes.

\section{Conclusions}

Since there are many projects to invest in and organizations have limited capital, they should choose a subset of the different projects that are available to them. To do this, first of all it is necessary to evaluate the current portfolio. The results of the study and the findings show that thanks to the developed indicators, oil and gas companies can assess the current portfolio from the standpoint of strategy, financial and operational results, rank existing and potential projects, take into account the impact of various aspects on their activities, as well as proactively respond to environmental changes, achieve goals and maximize profitability.

\section{Acknowledgements}

The study was financially supported by the Russian Foundation for Basic Research (RFBR), Project No. 18010-00734 "Forming Methodology for Technological Forecasting of the Development of Interrelated Industrial and Socio-Economic Systems in Exploring Hydrocarbon Resources in the Arctic".

\section{References}

1. A. Ilinova, A. Chanysheva, N. Kourentzes, I. Svetunkov, Innovation-Based Development of the Mineral Resources Sector: Challenges and Prospects: Proceedings of the 11th Russian-German Raw Materials Conference, 1 (2018)

2. N. Smirnova, A. Cherepovitsyn, A. Ilinova, European Research Studies Journal, volume XXI, 2 (2018)

3. A. Cherepovitsyn, A. Ilinova, European Research Studies Journal, volume XXI, 1 (2018)

4. A. Ilinova, A. Cherepovitsyn, O. Evseeva, Resources, 7 (2018)

5. K. Callahan, L. Brooks, Essentials of strategic project management (2004)

6. PMI, The Standard for Portfolio Management. Third Edition (2013)

7. Brandt M. W. Handbook of financial econometrics: Tools and techniques (2010)

8. H. Markowitz, The journal of finance, 1 (1952)

9. W. Sharpe, Financial Dec Making Under Uncertainty (1977)

10. Cifarelli G., Paladino G., Energy Economics, 32 (2010)

11. W. C. Kester, Harvard business review, 62 (1984)
12. S. Graves, J. Ringuest, European Journal of Operational Research, 1 (2004)

13. Danesh D., Ryan M. J., Abbasi A., International Journal of Management and Decision Making, 17 (2018)

14. R. Kaplan, Harvard Business Press (2001)

15. P. Chandra, Investment analysis and portfolio management, (2017)

16. M. Van Ittersum, Field Crops Research, 143 (2013)

17. S. Brown, T. Swartz, Journal of marketing, 2 (1989)

18. C. Killen, C. Kjaer, International Journal of Project Management, 5 (2012)

19. J. Pajares, A. López, Procedia-Social and Behavioral Sciences, 119 (2014)

20. M. Shafiee, L. Animah, B. Alkali, D. Baglee, Journal of Petroleum Science and Engineering, 173 (2019)

21. C. Luo, D. Wu, Environmental research, 149 (2016)

22. A. Frank, N. Dalle Molle, W. Gerstlberger, J. Bernardi, D. Pedrini, Journal of cleaner production, 133 (2016)

23. N. Antonakakis, J. Cunado, G. Filis, D. Gabauer, F. De Gracia, Energy Economics, 70 (2018)

24. A. Hope, R. Moehler, Procedia-Social and Behavioral Sciences, 119 (2014)

25. M. Hofman, S. Spalek, G. Grela, Sustainability, 10 (2017)

26. R. Killen, Effective teaching strategies: Lessons from research and practice (2006)

27. J. Finnerty, Project financing: Asset-based financial engineering (2013)

28. Dellote, Portfolio optimization for upstream oil and gas companies (2016)

29. Financial \& operating review, https://www.bp.com/

30. Financial \& operating review, https://www.chevron.com/

31. Financial \& operating review, https://corporate.exxonmobil.com/

32. Financial \& operating review, https://www.shell.com/

33. Financial \& operating review, https://www.total.com/

34. Financial \& operating review, https://www.equinor.com/

35. Financial \& operating review, https://www.eni.com/

36. E. Carayannis, A. Ilinova, A. Chanysheva, Journal of the Knowledge Economy (2019)

37. L. Eder, I. Filimonova, I. Provornaya, A. Komarova, S. Nikitenko, International Multidisciplinary Scientific GeoConference: SGEM: Surveying Geology \& mining Ecology Management, 17 (2017) 